\title{
A Detailed Sudy on a Rare Disease--: Charcot Marie Tooth (Cmt)
}

\author{
Lokesh Ranjan Mondal ${ }^{1}$, Raju Koneri ${ }^{2}$, Nagarathna P K M ${ }^{3}$. \\ ${ }^{1}$ M-Pharm ,Department Of Pharmacology, Karnataka College Of Pharmacy, Bangalore-Karnataka-India \\ ${ }^{2}$ Professor Of Department Of Pharmacology,Karnataka College Of Pharmacy, Bangalore-Karnataka-India. \\ ${ }^{3}$ Ass.Professor Of Department Of Pharmacology, Karnataka College Of Pharmacy,Bangalore-Karnataka-India.
}

Abstract: Charcot-Marie-Tooth (CMT) syndrome is now understood as a genetically diverse disorder with at least 25 underlying gene mutations identified to date. These encode proteins in different locations (myelin, Schwann cells and axons) with different functions but share the common final pathway of axonal degeneration, with a predilection for the largest and longest fibers. The typical CMT phenotype involves distal limb muscle wasting and sensory loss, with proximal pr-ogression over time. However, disease course is varied, reflecting both genotypic and phenotypic heterogeneity.

Charcot-Marie-Tooth, or progressive muscular atrophy of the personal type, was described in 1968 by Dyck ${ }^{(1,2)}$ as one of a group of hereditary motor sensory neuropathies (HMSN). It is a familial disease transmitted either by an autosomal dominant, X-linked recessive or autosomal recessive gene. This disease affects males more than females by a 5.1:3 ratio ${ }^{(3)}$. The reported incidence in the United States is 1 in 2,000 ${ }^{(4,5)}$, affecting more than 125,000 people. However, many clinicians state mild cases of Charcot Marie-Tooth may be underreported.

\section{Epidemiology}

It is the most common inherited neuromuscular disorder ${ }^{(6)}$ affecting 10-36/100,000 individuals. It has no predilection for a particular race or sex.

Charcot-Marie-Tooth disease (CMT) is ${ }^{(7)}$ among the most common inherited neurological disorders, with a prevalence reported ${ }^{(13,14)}$ as high as 36 per 100000 (Skre, 1974). The syndrome was initially described by Charcot and Marie in France (Charcot and Marie, 1886) and Tooth in England (Tooth, 1886) and confirmed ${ }^{(8,9)}$ to be a disorder of the PNS by Hoffman (Hoffmann, 1889). All these early investigators appreciated the fact that the disease was hereditary and often had its onset in childhood. In addition, they also recognized the characteristic clinical phenotype of distal leg weakness and atrophy, decreased sensation and absent reflexes. Little new was added to this description until the late 1950s, when Gilliatt and ${ }^{(15,16,17)}$ Thomas noted that some patients with CMT had slow nerve conduction velocities (NCVs) (Gilliatt and Thomas, 1957). Later, ${ }^{(18,19)}$ in the 1960s and 1970s, several groups also found that CMT patients could be divided into two classes: those with slow and those with normal NCV (CMT1 and CMT2, respectively). In an evaluation of over 200 patients with $\mathrm{CMT}^{(11)}$ Harding and Thomas demonstrated further that CMT1 and CMT2 both segregated mainly as an autosomal dominant trait (Harding and Thomas, 1980b), and confirmed the clinical description of the disease by Charcot, Marie and Tooth (Harding and Thomas, 1980a). Finally, Lewis and Sumner showed that CMT1 patients have uniformly slowed NCVs, in contrast with patients with acquired demyelinating neuropathies such as the Guillain-Barré syndrome or CIDP (chronic inflammatory demyelinating polyneuropathy) (Lewis and Sumner, 1982).

\section{Symptoms:}

A symptom is something the patient feels and reports, while a sign is something other people, including a doctor or a nurse may detect. For example, pain may be a symptom while a rash may be a sign.

CMT symptoms and their intensities ${ }^{(13)}$ may vary considerably from patient-to-patient, even among close relatives who have inherited the condition. In the most severe cases the patient may require a wheelchair, while others may need a leg brace, special shoes, or other orthopedic devices.

Symptoms of CMT gradually worsen over time - it is a progressive condition. Early signs and symptoms, especially among children, may not be detectable because they are so mild.

The following signs and symptoms may point towards childhood CMT: ${ }^{(2)}$

---The child is clumsier (more prone to accidents) than other children of the same age.

---Walking may be slightly different, because of difficulties in lifting their feet off the ground with each step.

---As the child lifts his/her feet, the toes may drop forward.

The following Signs and symptoms tend to become noticeable when the child has finished puberty and enters 
adulthood - when the body is fully developed - but they can occur at any age, from very young to late 70s. The most common signs and symptoms include ${ }^{(16,18,14):}$

---Weakness in the muscles of the lower feet, legs and ankles.Ankle becomes unstable because the feet are very highly arched, or less commonly, very flat.

---Hammertoes (curled toes),

---Lifting up of the foot is difficult because of weak ankle muscles (footdrop)

--- A step (stride) which is higher than normal (an awkward step/gait)

---Numbness in the arms and feet

---Changing leg shape - the section of the leg below the knee becomes very thin, while the thighs retain their normal muscle volume and shape (stork legs)

---As CMT progresses muscle weakness will affect the patient's arms and hands more and more.

Progressive signs and symptoms may include:

---The patient's hands and arms become more affected.

---Problems with manual dexterity, such as doing up buttons, or opening jars and bottle tops.

---Muscle and joint pain resulting from problems with walking and posture which place a strain on the body.

---Neuropathic pain cause by damaged nerves (less common).

\section{Pathogenesis}

Understanding how the periphery nerves function is important if you want to have a better appreciation of what causes CMT.

The periphery nerve consists of two main parts:

The axon the inside of the nerve. like the metal part of an electric cable. The electrical information between the brain and the limbs passes through the axon, in the same way electricity passes through the metal part of a cable (wire).

The myelin sheath - the insulation around the axon, in the same way a wire/cable may have some kind of plastic insulation around it. The myelin sheath wraps around the axon, protecting it, as well as helping restore the quality of the electrical signal.

Either the axon or myelin sheath, or both, may be affected when a patient has CMT - it depends on the type. Mutated (faulty) genes cause the disintegration of the myelin sheath. If the myelin sheath wastes away it becomes thinner and thinner, eventually the axon becomes damaged and the patient's muscles no longer receive clear messages from the brain, resulting in muscle weakness and loss of sensation (numbness).

In some types of CMT the axons are directly targeted; also as a result of faulty genes. For some reason the electrical signals are not transmitted at the required strength to activate muscles and senses, resulting in weaker muscles and poorer tactile sensitivity (numbness).

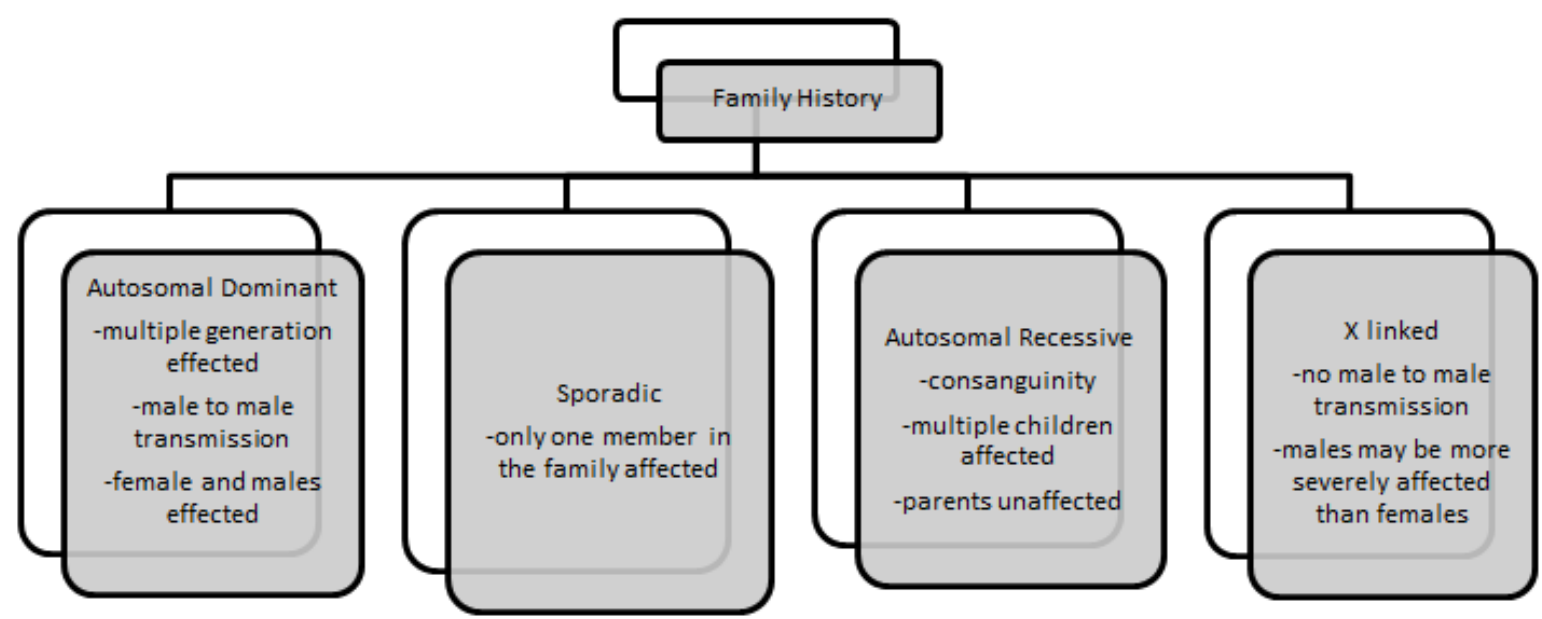

Nerve Conduction Velocity Testing 


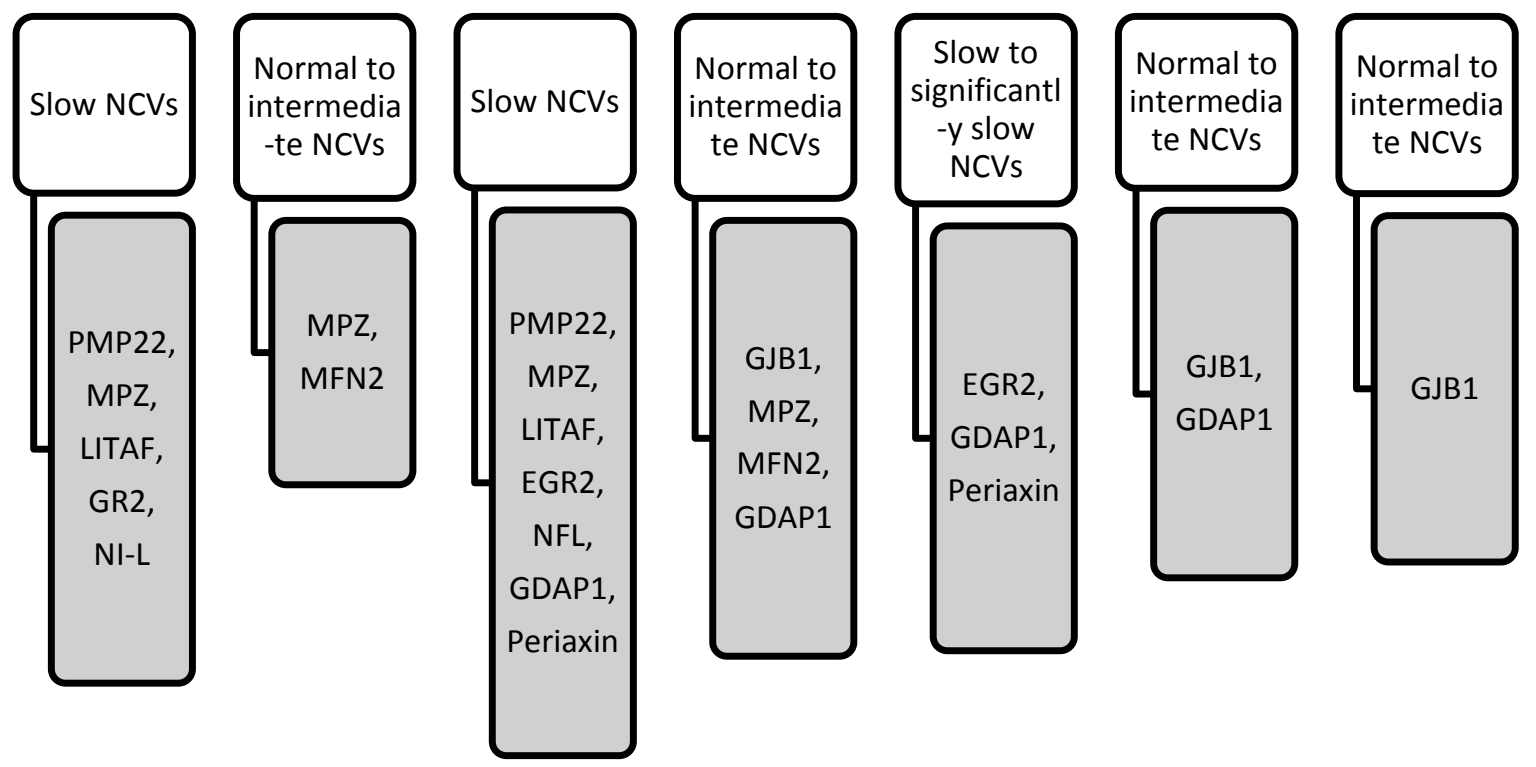

(NCV, nerve conduction velocity; PMP22, peripheral myelin protein gene; MPZ, myelin protein zero gene; LITAF,lipopolysaccharide-induced tumor necrosis factor-alpha factor gene; EGR2, early growth response gene 2; NFL, neurofilament.

light chain gene; MFN2, mitofusin 2 gene; GDAP1, ganglioside-induced differentiation-associated protein 1 gene; GJB1, gapjunction protein, beta-1 gene. *It is important that the family history is taken in a careful manner and that fit a given pedigree. ${ }^{*}$ NCV testing indicates velocity of impulses; amplitudes not included).

\section{There are various types of CMT:}

CMT 1 - the genes involved in myelin sheath production are faulty. The myelin sheath gradually wastes away. Approximately one third of all CMT cases are of this type.

CMT 2 - approximately $17 \%$ of all CMT cases. The defect is in the axon itself.

CMT 3 - also known as Dejerine-Sottas disease. This is a rare type of CMT. The myelin sheath is affected. The patient experiences severe muscle weakness and his/sense of touch is also affe-cted severely. Children with CMT 3 may have noticeable symptoms.

CMT 4 - also affects the myelin sheath. CMT 4 is rare. Experts believe several different genetic processes are involved in the development of CMT 4, but they are not sure which genes. Sym-ptoms generally appear during childhood. Wheelchairs are commonly required by patients with CMT 4.

CMT X - this type of CMT is caused by an X-chromosome mutation. This type of CMT is more commonly diagnosed in male patients. If female patients have CMT X, symptoms will be very mild. Approximately one tenth of all CMT cases in the UK are of this type.

Recent investigations into the genetic aetiology of the demyelinating form of CMT, CMT1, have demonstrated that the cause of the disease is heterogeneous. Bird and colleagues performed one of the first human genetic linkage studies on several families with CMT1 and showed that their disease was linked to the Duffy blood group locus on chromosome $1^{(16)}$. Most families with CMT1, however, are not linked to the chromosome 1 locus, but rather to a region on the short arm of chromosome 17 . In 1991, two groups showed that this form of CMT1, now called CMT1A, was associated with a $1.5 \mathrm{Mb}$ duplication on the short arm of chromosome $17^{(38)}$, which is now known to account for up to $80 \%$ of patients with CMT ${ }^{(35)}$. CMT1 linked to chromosome 1, now called CMT1B, is less common and is caused by mutations in the gene encoding the major PNS myelin structural protein, P0 ${ }^{(40)}$. Duplication of the PMP22 (peripheral myelin protein 22) gene, or CMT1A, thus accounts for most cases of demyelinating CMT and we will focus the rest of this paper on this entity. CMT is a genetic disease - it is an inherited disease. It is caused by inherited mutated genes that are involved in producing substances (proteins) which affect either the axon or myelin sheath of the peripheral nerve. In all cases of CMT, several mutated genes are involved in causing the condition (not just one).

The mutated genes may be inherited in several different ways:

Autosomal dominant - only one parent with the defective genes is needed for offspring to inherit the disease. If one of the parents has the defective genes, each offspring has a 50\% risk of developing the disease. 
Autosomal recessive - two copies of the defective gene are required for offspring to inherit the disease (and genetic defect). If each parent only has one copy, they do not have the disease themselves, but can pass it on to their children (if they have one copy each).

If both parents have the autosomal recessive CMT gene, each of their offspring has a $25 \%$ risk of developing CMT. Each offspring carries a 50\% risk of being a carrier - not having the disease but passing it on to their own offspring if their future partner also carries the autosomal recessive CMT gene.

$\mathrm{X}$-linked inheritance - this is where the mutated gene is located on the $\mathrm{X}$-chromosome and is inherited from a mother by her son.

Males have an $\mathrm{X}$ and a $\mathrm{Y}$ chromosome, while females have an $\mathrm{X}$ and an $\mathrm{X}$ chromosome. Males receive their $\mathrm{X}$ chromosome from their mothers and their $\mathrm{Y}$ chromosomes from their fathers. Females receive one $\mathrm{X}$ chromosome from their mothers and one $\mathrm{X}$ chromosome from their fathers.

A woman with a defective X-chromosome will either have no CMT symptoms, or very mild symptoms. This is because their other X-chromosome is healthy and makes up for the defects in the other one.

Male offspring have a 50\% risk of inheriting the defective X-chromosome and developing CMT.

If the mother has only daughters, CMT will not appear in her children, but may appear in the next generation if some of the grandchildren are male.

If the patient is seen by a GP (general practitioner, primary care physician), they may ask questions about symptoms and whether the patient has any relatives with the disease (family history). The GP will carry out a physical examination, looking out for evidence of muscle weakness, reduced muscle tone, flat feet, or high feet arches. If the GP suspects the patient may have CMT, he/she will be referred to a neurologist for further tests.

Nerve conduction studies - the aim here is to measure the strength and speed of the electrical signals that pass through the nerves. Electrodes, which are placed on the skin, deliver tiny electric shocks that stimulate the nerve. If there is either a delayed or weak response (or both), the patient most likely has a nerve disorder, and possibly CMT.

\section{Molecular Theory Of Cmt:}

The molecular architecture ${ }^{(21)}$ of the nerve is cruciallydependent on the finely tuned interactions between neurons,Schwann cells, and fibroblasts ${ }^{[22] .}$ In particular,Schwann cells and neurons provide signals to each otherthat regulate survival and differentiation throughout development ${ }^{[23]}$ Such interactions are also important inthe adult organism and in disease, as is becoming increasingly evident from studying the biology of Charcot-Marie-Tooth (CMT) disease. Disturbed communications between Schwann cells and neurons due to genetic defectsaffecting either one of these cell types are observed in these disorders.CMT syndromes are a group of genetically heterogeneous inherited neuropathies affecting the PNS, with are latively high prevalence of $1: 2,500^{[24]}$ They aregrouped by clinical and electrophysiological means into several subclasses ${ }^{[25]}$.

Recently, this classification has been refined based on fast progress in the understanding of the underlying genetic defects ${ }^{[26,27,28]}$ The main forms of CMT are subdivided into primary demyelinateing neuropathies (myelinopathies), which include CMT1(autosomal-dominant inheritance), CMT1X (X-linked),and CMT4 (autosomal-recessive), and neuropathies characterized by primary axonal defects such as CMT2(autosomaldominant or recessive).

Additional subforms of hypomyelinating and/or dysmyelinating neuropathies include Dejerine-Sottas syndrome (DSS, also called CMT3), hereditary neuropathies with liability to pressure palsies (HNPP), and congenital hypomyelination $(\mathrm{CH})$.Most patients suffer from demyelinating neuropathies ${ }^{[26]}$. This group is characterized by reduced nerve conduction velocity $(\mathrm{NCV})$, due to a partial or complete loss of the myelin sheet. Patients with primary axonopathies have been traditionally characterized by a reduced compound muscle action potential (CMAP), while NCV is normal or just slightly reduced ${ }^{[25]}$

This type of classification is still appropriate for proper diagnosis. Some overlap, however, is apparent in that specific mutations in a given disease gene, most notably Protein zero [MPZ(gene symbol)/P0 (commonly used abbreviation)] or connexin32 (GJB1/Cx32), manifest themselves either as CMT1 or CMT2 ${ }^{\text {[28] }}$.

This observation is likely due to different mutation-dependent disease mechanisms, but is also based on the emerging theme that alterations in Schwann cells will almost invariably also affect the neuronal partner cell and vice versa.In the last decade, a number of different genes with various mutations have been associated with inherited forms of neuropathies (Table $1 ;{ }^{[27]}$ ). The elucidation of the molecular basis started with the identification of point mutations in the peripheral myelin protein (Pmp22) gene in the natural mouse mutants 
Trembler (Tr) and Trembler-J (Tr-J) ${ }^{[29,30,31] . ~ P M P 22 ~ e n c o d e s ~ a n ~ i n t e g r a l ~ m e m b r a n e ~ p r o t e i n ~}{ }^{[33]}$ that is a significant component of compact PNS myelin ${ }^{[32,33,34,35,36]}$

In the following years, first mutations in MPZ ${ }^{[37,38]} \mathrm{GJB} 1{ }^{[39]}$ and the early growth response 2 gene (EGR2/Krox20) ${ }^{[40]}$ were found to be involved in the pathogenesis of different forms of CMT. The cell adhesion protein $\mathrm{P} 0$ is the major component of the compact myelin sheet in the PNS ${ }^{[41]} \mathrm{Cx} 32$ is a gap junction protein present in uncompacted PNS myelin domains and is probably involved in the transport of small molecules within Schwann cells ${ }^{[42]}$.

The transcription factor Krox 20 upregulates the expression of myelin genes ${ }^{[43,44]}$ In the last 2 years, the human genome project has facilitated the rapid discovery of at least six additional CMT genes, but there are still a number of known CMT loci awaiting the identification of the mutated genes .

Despite the rare occurrence of these CMT syndromes, they serve as natural models for investigation of the molecular mechanisms that are responsible for hereditary neuropathies. Mutations in the N-myc downstream regulated gene 1 (NDRG1) are responsible for HMSNLom ${ }^{[45]}$ mutations in the mytotubularin-related-protein-2 (MTMR2) lead to CMT4B1 $1^{[46]}$ and mutations in periaxin (PRX) were found in CMT4F ${ }^{[47,48]}$.

CMT2has been associated with mutations affecting the neurofilament light chain gene (NEFL) and kinesin 1B (KIF1B), while mutations in gigaxonin (GAN) lead to giant axonal neuropathy ${ }^{[49,50,51]}$.

\begin{tabular}{|c|c|c|c|c|c|c|}
\hline \multirow{17}{*}{$\begin{array}{l}\text { Table I Genes associated with } \\
\text { Charcot-Marie-Tooth (CMI) } \\
\text { syndromes (HNA hereditary } \\
\text { neuralgic amyotrophy) }\end{array}$} & OMIM & CMI form & Gened & Expression & Neuropathy & Inheritance \\
\hline & \multicolumn{6}{|c|}{ Dominant, demyelinating neluropathies } \\
\hline & 118220 & CMT1A & PMP22 & Schwann cell & Demvelinating & Dominant \\
\hline & 118200 & CMTIB & MPZ & Schwann cell & Demyelinating & Dominant \\
\hline & 601098 & CMIIC & & Schwann cell & Demyelinating & Dominant \\
\hline & 30800 & CMTIX & GIBI & Schrvann cell & Demyelinating & (Dominant) \\
\hline & 16550 & HNPP & PMP22 & Schwann cell & Demyelinating & Dominant \\
\hline & \multicolumn{6}{|c|}{ Axonal neluopothilies } \\
\hline & 118210 & CMI2A & KIFIB & Neuron & Axonal & Dominant \\
\hline & 600882 & CMILB & & & Axonal & Dominant \\
\hline & 605588 & CMILBI & Not.MPZ & & Axonal & Recessive \\
\hline & 605589 & CMIIB2 & Not EMP. 3 & & Axonal & Recessive \\
\hline & 601472 & CMI2D & & & Axonal & Dominant \\
\hline & 162280 & CMIVE & NEEL & Neuron & Axonal & Dominanant \\
\hline & 302801 & CMI2X & & & Axonal & Recessive \\
\hline & 256850 & GAN & GAN & N.D. & Axonal & Recessive \\
\hline & 162100 & HNA & & & Axonal? & Dominant \\
\hline
\end{tabular}

Recessive demyelinating neluropattilies

\begin{tabular}{|c|c|c|c|c|c|c|}
\hline & 214400 & CMT4A & & & Demyelinating & Recessive \\
\hline & 601382 & CMIABI & MTMR2 & N.D. & Demyelinating & Recessive \\
\hline & 604563 & CMTAB2 & & & Demyelinating & Recessive \\
\hline & 601596 & CMTAC & & & Demyelinating & Recessive \\
\hline & 601455 & CMI4D; Lom & NDRG1 & & Demyelinating & Recessive \\
\hline$C$ & 605253 & CMI4E & Eggr & Schwarnn cell & $\begin{array}{l}\text { Congenital } \\
\text { Hvpomvelination }\end{array}$ & Recessive \\
\hline of lip-10-date & 605725 & CMI4F & PRX & Schwann cell & Demyelinating & cessive \\
\hline
\end{tabular}


Fig. 1 Distribution of CharcotMarie-Tooth (CMT) loci in the human genome. CMT is a clinically and genetically heterogeneous syndrome. It is subdivided into CMT1 (demyelinating, dominant) CMT2 (axonal, dominant or recessive), and CMT4 (demyelinating, recessive). CMT3 (DejerineSottas syndrome, DSS) is genetically heterogeneous
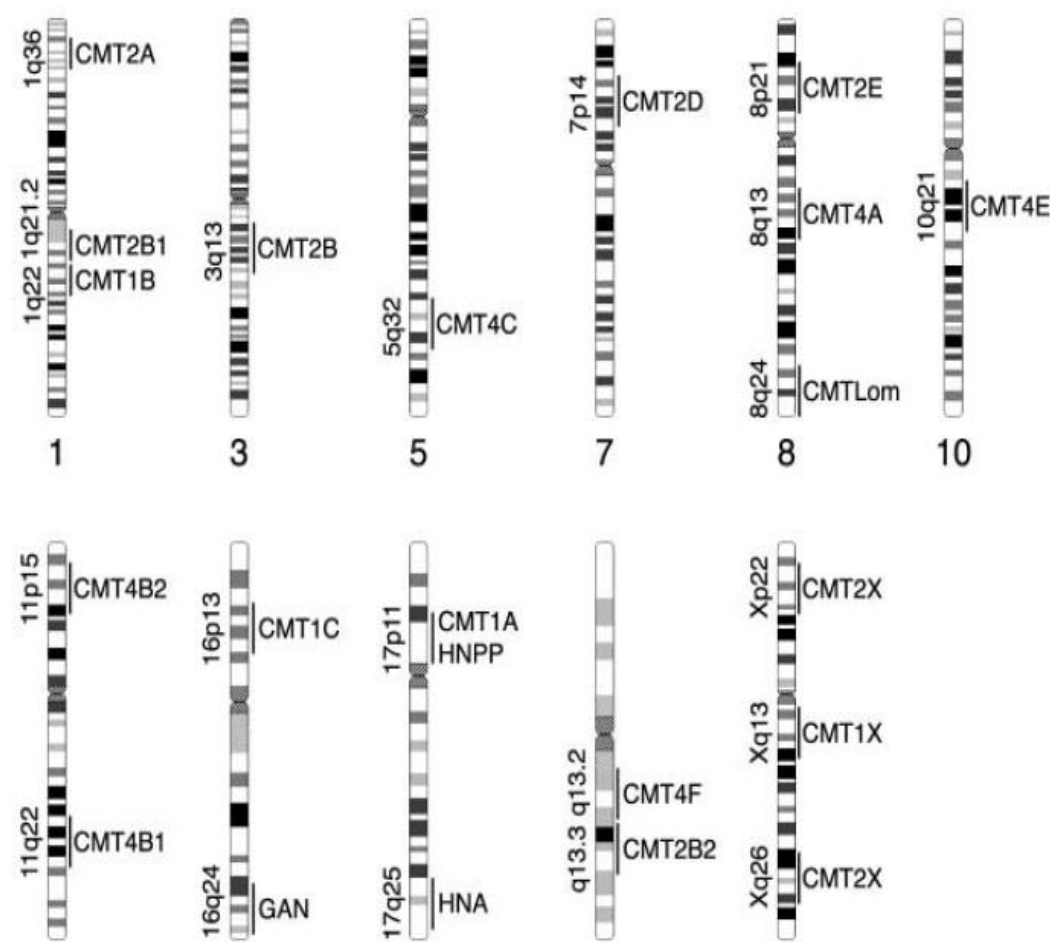

11



19

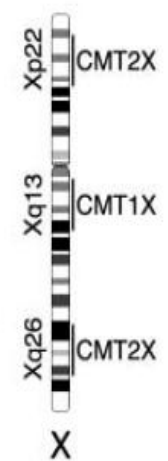

Fig. 2 Localization of proteins involved in CMT pathogenesis. Schematic drawing of a myelinated axon at the node of Ranvier (middle). KIF1B $\beta$ is a member of the kinesin super-

family. NF-L is a component of neurofilaments, the major intermediate filament in neurons

(upper left). L-periaxin is localized at the abaxonal membrane as a linker between the basal lamina and the cytoskeleton (upper right). $\mathrm{P} 0$ and $\mathrm{PMP} 22$ are major proteins of compact myelin. P0 forms homophilic tetramers that interact with PMP22 in cis or trans. Connexin 32 is a transmembrane protein localizing to the SchmidtLantermann incisures and the paranodal loops

Neurofilaments hypophosphorylated phosphorylated
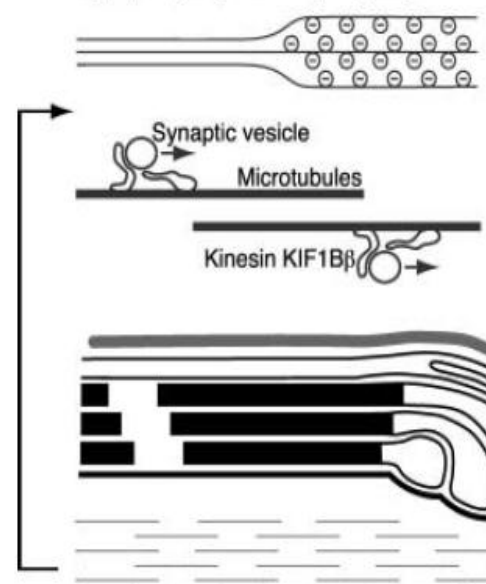

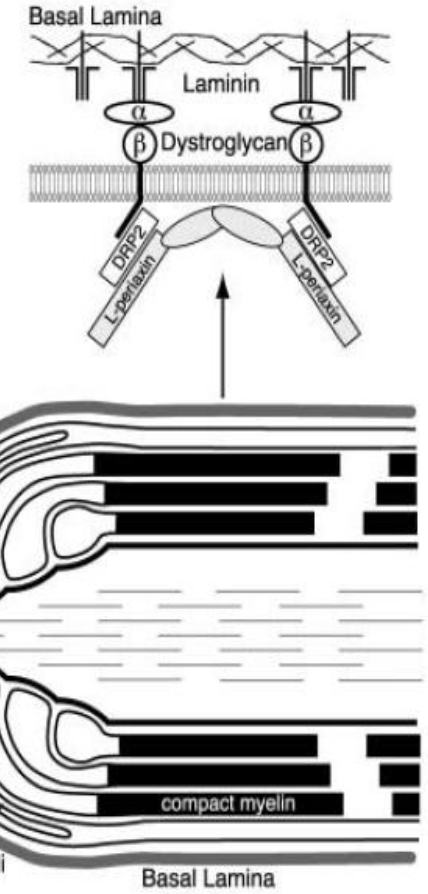

Basal Lamina

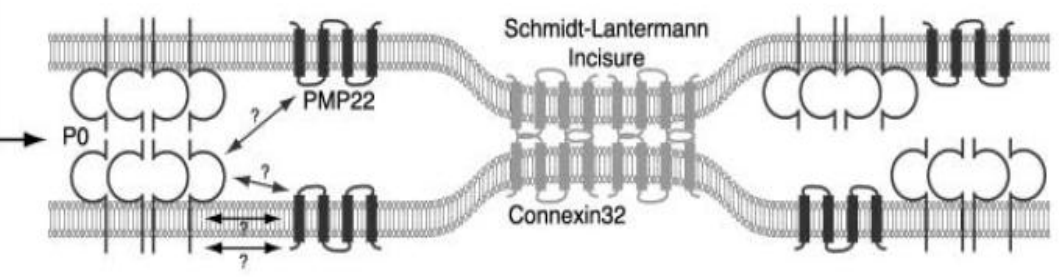




\section{Diagnosis:}

The diagnosis of Charcot-Marie-Tooth is usually made by a neurologist ${ }^{(2)}$.

Biopsy - the doctor makes an incision through the skin of the calf and takes a small piece of peripheral nerve the sample is tested in a lab. This test can tell whether the patient has CMT or some other nerve disorder.

A nerve biopsy is done, and when positive, shows hypertrophic endoneurial changes as "onion bulb" formations of nerve sheath tissue. This hypertrophy of the axon portion of the neuron is caused by the demyelination and attempted remyelination of the sheath .

\section{EMG (electromyography)-}

Nerve conduction velocities in a severely involved patient can be slowed by half. The molecular pathogeneses of hereditary peripheral neuropathies are disputed by researchers. The changes in the nerve tissue are noted in the posterior columns of the spinal cord, the spinal roots and the peripheral nerves. Physical Manifestations Although orthotic intervention is usually sought when deformity of the lower extremities or weakness causes some form of dysfunction in a patient, the well-informed practitioner should be aware of the other physical and clinical problems associated with Charcot Marie-Tooth.

Patients may have diminished deep tendon reflexes, dysphasia and French nerve involvement. There is also a reported 10 percent incidence of scoliosis. The characteristic changes seen in the upper extremities are intrinsic atrophy of the hands and weakness of the radially innervated muscle of the forearms (see the Figure given below ). The physical condition in the lower extremities reveals muscular atrophy usually distal to the knees. This situation is often described as "stork legs" (see the Figure given below ). Muscle weakness is almost always bilaterally symmetrical in the lower limbs.

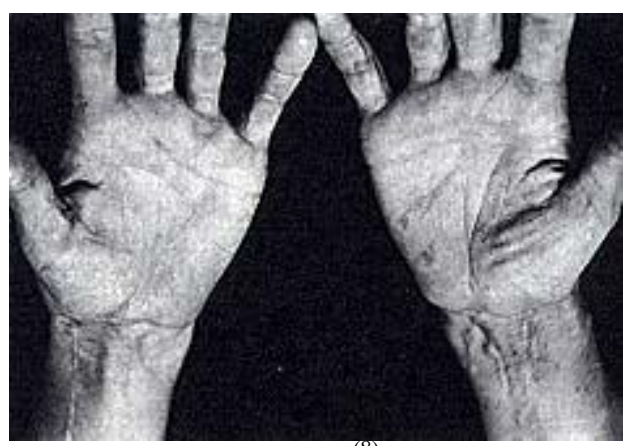

Figur:3: Intrinsic muscle ${ }^{(8)}$ wasting in hands.

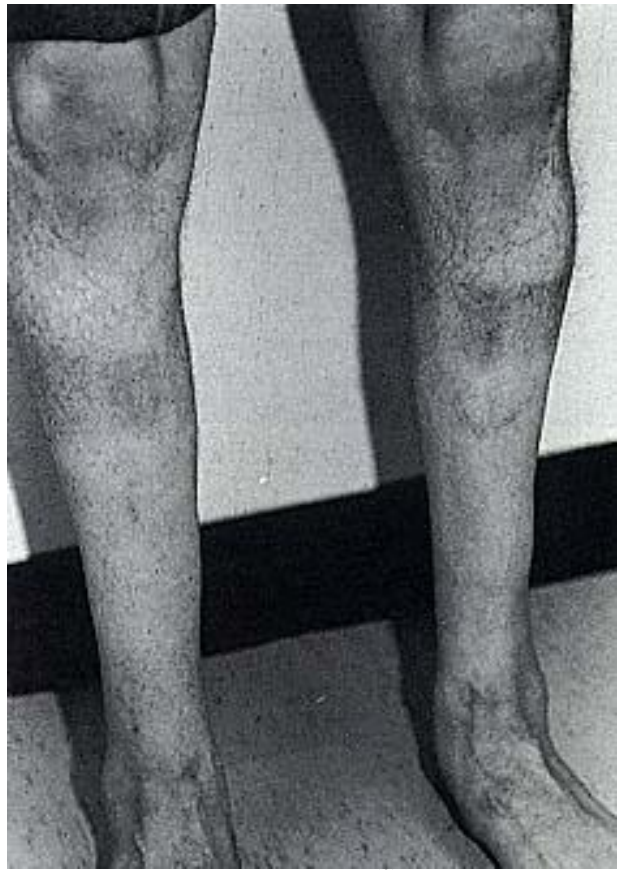

Figure 4: "Stork legs" appearance usually seen in Hereditary ${ }^{(8)}$ Motor Sensory Neuropathy type I. This muscular atrophy is most noticeable distal to knees. 
The foot often has cavus deformities and claw toes. Also, the forefoot has a tendency to be adducted and the heel to be in varus. The etiology of the foot deformities can be attributed to the sequence of denervation of the muscles of the lower limb.

Since the demyelination presumably occurs at the same rate, it is thought that the cross-sectional density at the muscle belly dictates the rate of weakness seen. Therefore, the peroneus brevis, a foot evertor, is first affected and overpowered by the posterior tibialis muscle, resulting in the foot's inversion. The peroneus longus, with its insertion on the plantar aspect of the first ray, will usually plantarfiex that ray and the rest of the forefoot into a semi-rigid forefoot equinus (see the Figure given in below ) since the dorsiflexor antagonist of the peroneus longus, the anterior tibialis, is too weak to prevent it. The heel is pulled into varus with contraction of the plantar fascia and ligaments .

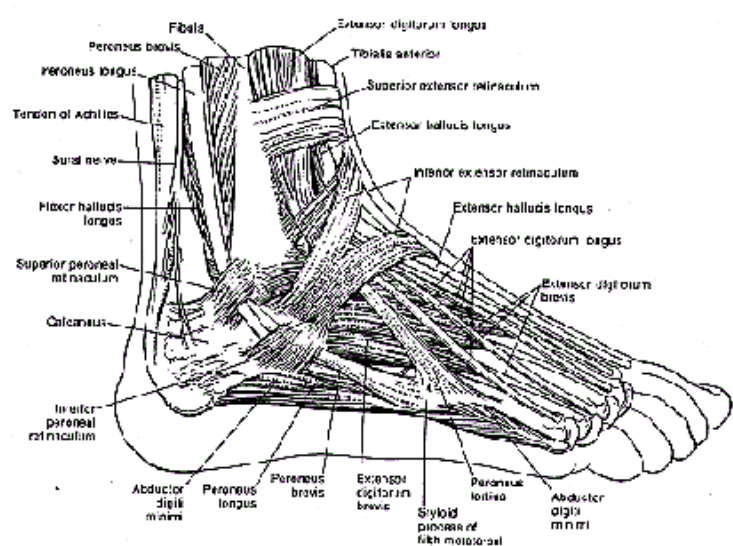

Figure 5: Peroneus brevis inserts into the ${ }^{(8)}$ base of the 5th metatarsal while the peroneus longus inserts at plantar aspect of 1st metatarsal shaft .

Genetic testing - this is done by extracting a sample of the patient's blood. The doctor and patient will then know whether the patient carries the faulty gene(s). There is a chance that this test remains inconclusive because not all the faulty genes are identifiable.

\section{TREATMENT:}

CMT is an incurable disease - there is nothing modern medicine can to get rid of the disease. However, some therapies may help relieve some of the ${ }^{(10)}$ signs and symptoms, as well as delaying the start of eventual physical disabilities.

Pain - People with CMT may experience either/both types of pain described below:

Joint and muscle pain - resulting from stresses that are placed on parts of the body because of CMT.

NSAIDs (non-steroidal anti-inflammatory drugs), such as ibuprofen, can help reduce joint and muscle pain.

Neuropathic pain - caused by damaged nerves (less common).

NSAIDs can sometimes help alleviate the symptoms of neuropathic pain.

TCAs (tricyclic antidepressants) - if NSAIDs are not effective, the patient may be prescribed a TCA. TCAs, although originally designed to treat patients with depression, are also effective in alleviating neuropathic pain symptoms. TCAs may have the following side effects:

Constipation

Sweating

Problems urinating

Vision problems (blurring)

Drowsiness

Dry mouth

As the body gets used to the medication the side-effects usually go away - after 7 to 10 days. Patients taking a TCA should not take cannabis is it may accelerate the heartbeat.

Physical therapy (UK: physiotherapy) - with a good physical therapist the patient can strengthen and stretch muscles, which help maintain muscle strength for longer and prevent muscle tightening. Sessions usually involve low-impact exercises and stretching techniques. If physical therapy starts early on, it can make a significant difference in slowing down nerve deterioration and muscle weakness, resulting in a delay of disabilities. 
Occupational therapy - this may help patients who have problems with finger movements and gripping, which may severely affect the individual's ability to do up button's, write, or carry out otherwise straightforward activities, such as turning a door-knob, opening a bottle or jar, or tying up shoelaces.

Devices - these are usually orthopedic devices which help the individual maintain mobility and prevent injury. Leg and ankle braces or splints can help the patient walk and go upstairs. High top shoes or special boots may provide extra ankle support. Specially made shoe inserts, or even shoes, may help the individual maintain a better gait. Thumb splints may help with dexterity.

If the patient has scoliosis - curvature of the spine - he/she may have to wear a back brace. In very severe cases surgery may be required.

Surgery - in severe cases, the patient's foot may require surgical intervention to alleviate pain and make walking easier. Possible surgical procedures include:

Osteotomy - used to correct severe flat feet. The surgeon either repositions or removes bones in the foot. After the operation the foot will be in plaster for a number of weeks.

Arthrodesis - used to correct flat feet, relieve joint pain, and correct heel deformities. The three main joints in the back of the feet are fused, resulting in a stronger foot, better shape, and often less pain. After surgery the foot will be placed in a cast for a number of weeks. It can take up to 10 months before the foot recovers completely.

Planter fascia release - inflamed tendons can cause continuous heel pain. Part of the tendon is surgically removed, while the remaining tendon is repositioned. The patient's foot will be in a cast for about 3 weeks.

\section{Possible complications:}

Breathing - if the nerves that control the diaphragm are affected the patient may feel out of breath. The doctor may prescribe bronchodilator medications. If symptoms are severe the patient may need a ventilator. Obese/overweight people with CMT and breathing difficulties will find that their breathing is easier if they lose weight.

Depression - the mental stresses, anxieties and frustrations of living with a progressive disease, such as CMT, can eventually raise the risk of developing depression. It is important to see your doctor if you have any of the signs and symptoms of depression. Joining a support group, where you can meet other people who have something in common with you can also help. CBT(cognitive behavioral therapy) may also help lower the risk of developing depression (see below).

CBT (cognitive behavioral therapy) - CBT has been shown to help patients with CMT cope better. CBT trains the patient to react differently to his/her condition. CBT includes relaxation techniques as well as maintaining a positive outlook, resulting in less pain and mental stress.

\section{NEW CLINICAL APPROACHES:}

Ascorbic acid treatment of the animal model ofCMT1A has improved ${ }^{(51)}$ myelination and reduced PMP22 levels in affected rats. A multicenter international clinical trial is already on the way that uses high-dose ascorbic acid for treatment in patients with CMT1 $\mathrm{A}^{.(52)}$.Another exciting new approach is based on data obtained in the animal model of CMT1A, which showed that a selective progesterone antagonist, onapristone, reduced PMP22 overexpression in tissue culture and improved the CMT phenotype in CMT1A rats. ${ }^{.(3)}$

\section{Conclusions:}

Inherited neuropathies are among the most prevalent genetic neurologic diseases.They affectthe quality of life of the patients.There is no particular therapy to treat this diseases. So the treatment of these diseases challenges families and healthcare workers. The research on this CMT is still going on in various countries research center.

\section{References:}

[1]. Dyck PJ, Lamber EH. Lower motor and primary sensory neuron diseases with peroneal muscular atrophy I: Neurologic, genetic and electrophysiological findings in hereditary polyneuropathies. Arch Neurol June 1968; 18:603-18

[2]. Dyck PJ, Lamber EH. Lower motor and primary sensory neuron diseases with peroneal muscular atrophy II: Neurogenic, genetic and electrophysiological findings in various neuronal degenerations. Arch Neurol 1968; 18:619-25.

[3]. Charcot-Marie-Tooth Association- personal inquiry. CMT International, 34B Bayview Drive, St. Catherine, Ontario, Canada L2N $4 \mathrm{Y} 6$

[4]. Jacobs H. The neuropathic foot. Albany: Albany Medical College, 1978;12:247.

[5]. European Journal of Human Genetics (2009) 17, 703-710 \& 2009 Macmillan Publishers Limited All rights reserved 1018-4813/09

[6]. Charcot-Marie-Tooth Disease ,Author: Divakara Kedlaya, MBBS; Chief Editor: Jason H Calhoun, MD, FACS

[7]. Charcot-Marie-Tooth Disease Type 2A Caused by Mutation in a Microtubule Motor KIF1B

[8]. Orthotic Management of Charcot-Marie Tooth John J. Kamp, CO, OPA

[9]. Charcot-Marie-Tooth Disease: Lessons in Genetic Mechanisms ,James R. Lupski Department of Molecular and Human Genetics, Department of Pediatrics, and Texas Children's Hospital, Baylor College of Medicine, Houston, Texas, U.S.A.

[10]. A New Variant of Charcot-Marie-Tooth Disease Type 2 Is Probably the Result of a Mutation in the Neurofilament-Light Gene. Irina V. Mersiyanova,1 Alexander V. Perepelov,4 Alexander V. Polyakov,1 Vladimir F. Sitnikov,2 Elena L. Dadali,1 Roman B. 
Oparin,3 Alexander N. Petrin,1 and Oleg V. Evgrafov11Research Centre for Medical Genetics, 2Russian State Medical University, and 3Research Center for Dermatology and Venerology, Moscow; and 4State University of Mordovia, Saransk, Russia

[11]. Pathologic Basis of Disease by Robbins and Cotran

[12]. Andres PL, Hedlund W, Finison L, Conlon T, Felmus M, Munsat TL. Quantitative motor assessment in amyotrophic lateral sclerosis. Neurology 1986; 36: 937-41.

[13]. Behse F, Buchthal F. Peroneal muscular atrophy (PMA) and related disorders. II. Histological findings in sural nerves. Brain 1977; 100: $67-85$.

[14]. Berciano J, Combarros O, Calleja J, Polo JM, Leno C. The application of nerve conduction and clinical studies to genetic counselling in hereditary motor and sensory neuropathy type I. Muscle Nerve 1989; 12: 302-6.

[15]. Bird TD, Ott J, Giblett ER. Evidence for linkage of Charcot-Marie-Tooth neuropathy to the Duffy locus on chromosome 1. Am J Hum Genet 1982; 34: 388-94.

[16]. Birouk N, Gouider R, Le Guern E, Gugenheim M, Tardieu S, Maisonobe T, et al. Charcot-Marie-Tooth disease type 1A with 17 p11.2 duplication: clinical and electrophysiological phenotype study and factors influencing disease severity in 119 cases. Brain 1997; 120: 813-23.

[17]. Bouche P, Gherardi R, Cathala HP, Lhermitte J, Castaigne P. Peroneal muscular atrophy. Part 1. Clinical and electrophysiological study. J Neurol Sci 1983; 61: 389

[18]. Brust JC, Lovelace RE, Devi S. Clinical and electrodiagnostic features of Charcot-Marie-Tooth syndrome. Acta Neurol Scand Suppl 1978; 68: 1-142.

[19]. Philipp Berger - Peter Young - Ueli Suter Molecular cell biology of Charcot-Marie-Tooth diseases.

[20]. Jessen KR, Mirsky R (1999) Schwann cells and their precursors emerge as major regulators of nerve development. Trends Neurosci 22:402-410

[21]. Lobsiger CS, Taylor V, Suter U (2002) The early life of a Schwann cell. Biol Chem (in press)

[22]. Skre H (1974) Genetic and clinical aspects of Charcot-Marie-Tooth's disease. Clin Genet 6:98-118

[23]. Dyck PJ, Chance P, Lebo R, Carney JA (1993) Hereditary motor and sensory neuropathies. In: Dyck PJ, Thomas PK, Grffin JW, Low PA, Poduslo JF (eds) Peripheral neuropathy, 3rd edn. Saunders, Philadelphia, pp1094-1136.

[24]. Nelis E, Haites N, Van Broeckhoven C (1999) Mutations in the peripheral myelin genes and associated genes in inherited peripheral neuropathies. Hum Mutat 13:11-28

[25]. Warner LE, Garcia CA, Lupski JR (1999) Hereditary peripheral neuropathies: clinical forms, genetics, and molecular mechanisms. Annu Rev Med 50:263-275

[26]. Young P, Suter U (2001) Disease mechanisms and potential therapeutic strategies in Charcot-Marie-Tooth disease. Brain Res Brain Res Rev 36:213-221

[27]. Vance JM (1999) Charcot-Marie-Tooth disease type 2. Ann N Y Acad Sci 883:42-46

[28]. Suter U, Welcher AA, Ozcelik T, Snipes GJ, Kosaras B, Francke U, Billings GS, Sidman RL, Shooter EM (1992) Trembler mouse carries a point mutation in a myelin gene.Nature 356:241-244

[29]. Suter U, Moskow JJ, Welcher AA, Snipes GJ, Kosaras B, Sidman RL, Buchberg AM, Shooter EM (1992) A leucine-toproline mutation in the putative first transmembrane domain of the 22-kDa peripheral myelin protein in the trembler-J mouse. Proc Natl Acad Sci USA 89:4382-4386

[30]. Taylor V, Zgraggen C, Naef R, Suter U (2000) Membrane topologyof peripheral myelin protein 22. J Neurosci Res 62:15-27

[31]. Welcher AA, Suter U, De Leon M, Snipes GJ, Shooter EM (1991) A myelin protein is encoded by the homologue of a growth arrest-specific gene. Proc Natl Acad Sci USA 88: 7195-7199

[32]. Spreyer P, Kuhn G, Hanemann CO, Gillen C, Schaal H, Kuhn R, Lemke G, Muller HW (1991) Axon-regulated expression of a Schwann cell transcript that is homologous to a 'growth arrest-specific' gene. EMBO J 10:3661-3668

[33]. Snipes GJ, Suter U, Welcher AA, Shooter EM (1992) Characterization of a novel peripheral nervous system myelin protein (PMP22/SR13). J Cell Biol 117:225-238

[34]. Haney C, Snipes GJ, Shooter EM, Suter U, Garcia C, Griffin JW, Trapp BD (1996) Ultrastructural distribution of PMP22 in Charcot-Marie-Tooth disease type 1A. J Neuropathol Exp Neurol 55:290-299

[35]. Jetten AM, Suter U (2000) The peripheral myelin protein 22 and epithelial membrane protein family. Prog Nucleic Acid Res Mol Biol 64:97-129

[36]. Hayasaka K, Himoro M, Sato W, Takada G, Uyemura K, Shimizu N, Bird TD, Conneally PM, Chance PF (1993) Charcot-MarieTooth neuropathy type $1 \mathrm{~B}$ is associated with mutations of the myelin P0 gene. Nat Genet 5:31-34

[37]. Warner LE, Hilz MJ, Appel SH, Killian JM, Kolodry EH, Karpati G, Carpenter S, Watters GV, Wheeler C, Witt D, Bodell A, Nelis E, Van Broeckhoven C, Lupski JR (1996) Clinical phenotypes of different MPZ (P0) mutations may include Charcot-Marie-Tooth type 1B, Dejerine-Sottas, and congenital hypomyelination. Neuron 17:451-460

[38]. Bergoffen J, Scherer SS, Wang S, Scott MO, Bone LJ, Paul DL, Chen K, Lensch MW, Chance PF, Fischbeck KH (1993) Connexin mutations in X-linked Charcot-Marie-Tooth disease. Science 262:2039-2042

[39]. Warner LE, Mancias P, Butler IJ, McDonald CM, Keppen L,Koob KG, Lupski JR (1998) Mutations in the early growth response2 (EGR2) gene are associated with hereditary myelinopathies. Nat Genet 18:382-384

[40]. Suter U (1997) Myelin: keeping nerves well wrapped up. Curr Biol 7:R21-R23

[41]. Balice-Gordon RJ, Bone LJ, Scherer SS (1998) Functional gap junctions in the schwann cell myelin sheath. J Cell Biol 142:10951104

[42]. Topilko P, Schneider-Maunoury S, Levi G, Baron-Van Evercooren A, Chennoufi AB, Seitanidou T, Babinet C, Charnay P (1994) Krox-20 controls myelination in the peripheral nervous system. Nature 371:796-799

[43]. Nagarajan R, Svaren J, Le N, Araki T, Watson M, Milbrandt J (2001) EGR2 mutations in inherited neuropathies dominantnegatively inhibit myelin gene expression. Neuron 30:355-368

[44]. Kalaydjieva L, Gresham D, Gooding R, Heather L, Baas F, Jonge R de, Blechschmidt K, Angelicheva D, Chandler D, Worsley P, Rosenthal A, King RH, Thomas PK (2000) N-myc downstream-regulated gene 1 is mutated in hereditary motor and sensory neuropathy-Lom. Am J Hum Genet 67:47-58

[45]. Bolino A, Muglia M, Conforti FL, LeGuern E, Salih MA, Georgiou DM, Christodoulou K, Hausmanowa-Petrusewicz I, Mandich P, Schenone A, Gambardella A, Bono F, Quattrone A, Devoto M, Monaco AP (2000) Charcot-Marie-Tooth type 4B is caused by mutations in the gene encoding myotubularinrelated protein-2. Nat Genet 25:17-19

[46]. Guilbot A, Williams A, Ravise N, Verny C, Brice A, Sherman DL, Brophy PJ, LeGuern E, Delague V, Bareil C, Megarbane A, Claustres M (2001) A mutation in periaxin is responsible for CMT4F, an autosomal recessive form of Charcot-Marie-Tooth disease. Hum Mol Genet 10:415-421 
[47]. Boerkoel CF, Takashima H, Stankiewicz P, Garcia CA, Leber SM, Rhee-Morris L, Lupski JR (2001) Periaxin mutations cause recessive Dejerine-Sottas neuropathy. Am J Hum Genet 68:325-333

[48]. Mersiyanova IV, Perepelov AV, Polyakov AV, Sitnikov VF, Dadali EL, Oparin RB, Petrin AN, Evgrafov OV (2000) A new variant of Charcot-Marie-Tooth disease type 2 is probably the result of a mutation in the neurofilament-light gene. Am J Hum Genet 67:3746

[49]. Bomont P, Cavalier L, Blondeau F, Ben Hamida C, Belal S, Tazir M, Demir E, Topaloglu H, Korinthenberg R, Tuysuz B, Landrieu P, Hentati F, Koenig M (2000) The gene encoding gigaxonin, a new member of the cytoskeletal BTB/kelch repeat family, is mutated in giant axonal neuropathy. Nat Genet 26: 370-374

[50]. Zhao C, Takita J, Tanaka Y, Setou M, Nakagawa T, Takeda S, Yang HW, Terada S, Nakata T, Takei Y, Saito M, Tsuji S, Hayashi Y, Hirokawa N (2001) Charcot-Marie-Tooth disease type 2A caused by mutation in a microtubule motor KIF1Bbeta. Cell 105:587597

[51]. Charcot-Marie-Tooth Neuropathies: Diagnosis and Management Agnes Jani-Acsadi, M.D.,1 Karen Krajewski, M.S.,1 and Michael E. Shy, M.D.1

[52]. Passage E, Norreel JC, Noack-Fraissignes P, et al. Ascorbic acid treatment corrects the phenotype of a mouse model of CharcotMarie-Tooth disease. Nat Med 2004;10:396-401

[53]. Sereda MW, Meyer Zu Horste G, Suter U, Uzma N, Nave KA. Therapeuticadministration of progesterone antagonist in a model of Charcot-Marie-Tooth disease (CMT-1A). Nat Med 2003;9:1533-1537 